\title{
Reference Transcriptome Assembly and Annotation for Perennial Ryegrass
}

\begin{tabular}{|r|l|}
\hline Journal: & Genome \\
\hline Manuscript ID & gen-2017-0077.R1 \\
\hline Manuscript Type: & Note \\
\hline Date Submitted by the Author: & 10 -Jul-2017 \\
\hline Complete List of Authors: & $\begin{array}{l}\text { Shinozuka, Hiroshi; Agriculture Victoria } \\
\text { Cogan, Noel; Agriculture Victoria } \\
\text { Spangenberg, German; Agriculuture Victoria, Biosciences Research } \\
\text { Forster, John; Agriculuture Victoria, Biosciences Research }\end{array}$ \\
\hline $\begin{array}{r}\text { Is the invited manuscript for } \\
\text { consideration in a Special } \\
\text { Issue? : }\end{array}$ & This submission is not invited \\
\hline Keyword: & Lolium, pasture, RNA-Seq, unigene, candidate gene \\
\hline
\end{tabular}

\section{SCHOLARONE \\ Manuscripts}




\section{NOTE}

3 Reference Transcriptome Assembly and Annotation for

4 Perennial Ryegrass

6 H. Shinozuka, N.O.I. Cogan, G.C. Spangenberg, and J.W. Forster

8 H. Shinozuka, N.O.I. Cogan, G.C. Spangenberg, J.W. Forster

9 Agriculture Victoria, AgriBio, the Centre for AgriBioscience, 5 Ring Road, Bundoora,

10 Victoria 3083, Australia.

11 N.O.I. Cogan, G.C. Spangenberg, J.W. Forster

12 School of Applied Systems Biology, La Trobe University, Bundoora, Victoria 3086,

13 Australia.

14 Corresponding author: John W. Forster (email: john.forster@ecodev.vic.gov.au) 


\section{Abstract}

2 RNA-Seq methodology has been used to generate a comprehensive transcriptome

3 sequence resource for perennial ryegrass, an important temperate pasture grass

4 species. A total of $931,547,255$ reads were obtained from libraries corresponding to

519 distinct tissue samples, including both vegetative and reproductive stages of

6 development. Assembly of data generated a final filtered reference set of 48,713

7 contigs and scaffolds. The transcriptome resource will support whole genome

8 sequence assembly, comparative genomics, implementation of genotyping-by-

9 sequencing (GBS) methods based on transcript sampling and identification of

10 candidate genes for multiple biological functions.

11

12 Keywords: Lolium, pasture, RNA-Seq, unigene, candidate gene, breeding 


\section{Introduction}

2 Perennial ryegrass (Lolium perenne L.) is a globally important pasture grass of

3 temperate livestock production systems. Perennial ryegrass is a member of the

4 Pooideae (cool-season) sub-family of the grass and cereal family Poaceae (Soreng

5 et al. 2015), with a chromosomal constitution of $2 n=2 x=14$ and an estimated

6 haploid genome size of c. 2.6 Gbp (Kopecký et al. 2010). A number of genomic

7 resources have previously been generated for this species, to support applications

8 such as transgenic modification (Tu et al. 2010) and genomics-assisted breeding

9 (Forster et al. 2008). Several comprehensive expressed sequence tag (EST)

10 collections (Sawbridge et al. 2003; Asp et al. 2007) were obtained by Sanger

11 sequencing. More recently, RNA-Seq methodology has been used for de novo

12 transcriptome assembly in perennial ryegrass (Farrell et al. 2014) and the closely

13 related species, Italian ryegrass (Lolium multiflorum Lam.) (Stočes et al. 2016).

14 Given that a draft genome assembly for perennial ryegrass has also been generated

15 (Byrne et al. 2015), but genome coverage is incomplete, further efforts to define a

16 comprehensive unigene set are desirable, and sampling of the gene-space by

17 transcriptome offers an efficient and cost-effective solution. This study describes the

18 generation, characterisation and properties of RNA-Seq data from multiple tissue

19 types of single perennial ryegrass genotype, as a resource for use in applied pasture

20 plant improvement.

\section{Materials and methods}

23 A total of 19 distinct tissue samples (Table 1) were obtained from a single plant

24 genotype derived from the cultivar Grasslands Impact (AgResearch, New Zealand),

25 designated Impact $_{04}$ (Kaur et al. 2015). RNA extraction for all samples was 
1 performed using the RNeasy plant kit following manufacturer's instructions (Qiagen,

2 Hilden, Germany) followed by the TruSeq RNA library prep kit following

3 manufacturer's instructions (Illumina Inc., San Diego, California, USA). Libraries

4 were evaluated using the Bioanalyser (Agilent Technologies) and pooled and

5 quantified using the KAPA library quantification kit (KAPA Biosystems, Cape Town,

6 South Africa). Sequencing data was generated using the Illumina HiSeq platform

7 (Illumina Inc., San Diego, California, USA). Data was assembled through use of

8 SOAPdenovoTranscriptome v1.05 (Xie et al., 2014). Scaffolds that were identified as

9 forks, bubbles or complex were individually passed into the CAP3 assembly program

10 (Huang and Madan, 1999) in order to resolve loci into single contigs.

\section{Results}

13 A total of $931,547,255$ reads were used for sequence assembly. A range of k-mers

14 were empirically evaluated, and a final value of 51 was found to be optimal using a

15 total of $92.3 \%$ of reads in the assembly. A total of 480,391 contigs and scaffolds

16 were generated. Filtering of this initial assembly on the basis of sequence length

17 removed 156,810 entries $<149$ bp in length, taken as a minimum of the basis of

18 output characteristics, such that shorter contigs represented a single, or potentially

19 partial, sequence read. Short contigs and scaffolds (>149 bp but $<250 \mathrm{bp}$ ) were only

20 accepted when the average coverage was $>10$. This step removed a further 95,417

21 entries from the reference. A total of 86,290 entries in the initial assembly that

22 related to 25,864 loci were processed by CAP3, generating 26,172 contigs that

23 related to 25,864 loci. All of these assembled contigs were combined with the

24 remainder to generate a consolidated quality filtered assembly of 168,046 contigs

25 and scaffolds. 
1 The quality filtered data set was then compared to the Uniref90 database

2 using BLASTX. An arbitrary E-value threshold of $<10^{-10}$ was applied for matches to

3 protein sequences in the database, and 60,278 contigs and scaffolds met this

4 criterion. The matched sequences were then further filtered, and any match that was

5 not to a plant species was removed $(11,565)$ leaving a final filtered reference set of

648,713 contigs and scaffolds, representing a core transcriptome for perennial

7 ryegrass. Sequences were further gap-filled if possible, generating a total length of

$870,192,231 \mathrm{bp}$, with a G/C content of $50.81 \%$. The N50 statistic identified 9,610

9 sequences of $\geq 2324$ bp. Full details of the RNA-Seq data from this study can be

10 accessed from NCBI BioProject PRJNA379202.

\section{Discussion}

13 Annotation of the present and any future draft genome assemblies for perennial 14 ryegrass will be assisted by provision of high-quality reference transcriptome data, in

15 order to increase confidence in gene prediction. In addition, alignment of perennial 16 ryegrass coding sequences to putative orthologues in the genomes of model

17 Poaceae species such as rice (Oryza sativa L.) and Brachypodium distachyon L. 18 permits inference of conserved syntenic relationships, in support the broad patterns 19 of conserved macrosynteny that have been previously established (Jones et al. 20 2002; Pfeifer et al. 2013). Reference transcriptome assembly is also desirable for 21 implementation of GBS methods based on sampling of transcription products as a 22 means for genome complexity reduction (Harper et al., 2012). Such methods of likely 23 to be of high value for species such as perennial ryegrass, due to large genome size 24 and high levels of heterozygosity, which may lead to substantial amounts of missing 25 data from GBS methods based on enzymatic cleavage of genomic DNA such as 
1 restriction-associated DNA (RAD) systems (Miller et al. 2007). Transcripts

2 sequenced by RNA-Seq from specific genotypes may be aligned to the Impact04

3 reference transcriptome to identify polymorphic DNA sequences suitable for use in

4 applications such as genome-wide association studies (GWASs) (Huang and Han

5 2014) and genomic selection (Meuwissen et al. 2001; Newell and Jannink 2014).

6 A comprehensive transcriptome resource is also valuable for identification of

7 candidate genes for core biological functions in perennial ryegrass, such as variation

8 of flowering time, oligosaccharide biosynthesis and lignification processes

9 (Shinozuka et al. 2012). In particular, evaluation of the reproductive development-

10 specific libraries will assist the identification of candidate genes for the gametophytic

11 self-incompatibility loci of perennial ryegrass, controlled by the $S$ and $Z$ loci

12 (Shinozuka et al., 2010; Manzanares et al., 2016).

\section{Acknowledgments}

15 This work was supported by the Victorian Department of Economic Development, 16 Jobs, Transport and Resources and the Dairy Futures Cooperative Research 17 Centre.

19 References

20 Asp, T., Frei, U.K., Didio, T., Nielsen, K.K., and Lübberstedt, T. 2007. Frequency, 21 type, and distribution of EST-SSRs from three genotypes of Lolium perenne, 22 and their conservation across orthologous sequences of Festuca 23 arundinacea, Brachypodium distachyon and Oryza sativa. BMC Plant Biol. 7: 36. 
1 Byrne, S.L., Nagy, I., Pfeifer, M., Armstead, I., Swain, S., Studer, B, Mayer, K., 2 Campbell, J.D., Czaban, A., Hentrup, S., Panitz, F., Bendixen, C., Hedegaard, 3 J., Caccamo, M., and Asp, T. 2015. A synteny-based draft genome sequence $4 \quad$ of the forage grass Lolium perenne. Plant J. 84: 816-826.

5 Farrell, J.D., Byrne, S., Paina, C., and Asp, T. 2014. De novo assembly of the

8 Forster, J.W., Cogan, N.O.I., Dobrowolski, M.P., van Zijll de Jong, E., Spangenberg,

Harper, A.L., Trick, M., Higgins, J., Fraser, F., Clissold, L., Wells, R., Hattori, C., Werner, P., and Bancroft, I. 2012. Associative transcriptomics of traits in the polyploidy crop species Brassica napus. Nat. Biotech. 30: 798-804.

Huang, X., and Madan, A. 1999. CAP3: a DNA sequence assembly program. Genome Res. 9: 868-877.

Huang, X., and Han, B. 2014. Natural variations and genome-wide association studies in crop plants. Ann. Rev. Plant Biol. 65: 531-551.

Jones, E.S., Mahoney, N.L., Hayward, M.D., Armstead, I.P., Jones, J.G., Humphreys, M.O., King, I.P., Kishida, T., Yamada, T., Balfourier, F., Charmet, C., and Forster, J.W. 2002. An enhanced molecular marker-based map of perennial ryegrass (Lolium perenne L.) reveals comparative relationships with other Poaceae species. Genome 45: 282-295.

Kaur, J., Ekanayake, P.N., Tian, P., van Zijll de Jong, E., Dobrowolski, M.P., 
Rochfort, S.J., Mann, R.C., Smith, K.F., Forster, J.W., Guthridge, K.M., Spangenberg, G.C. 2015. Discovery and characterisation of asexual Epichloë endophytes from perennial ryegrass (Lolium perenne L.). Crop Pasture Sci. 66: $1058-1070$.

Kopecký, D., Havránaková, M., Loureiro, J., Castro, S., Lukaszweski, A.J., Bartoš, J., Kopecká, J., and Doležel, J. 2010. Physical distribution of homoeologous recombination in individual chromosomes of Festuca pratensis in Lolium multiflorum. Cytogenetic Genome Res. 129: 162-172.

Manzanares, C., Barth, S., Thorogood, D., Byrne, S.L., Yates, S., Czaban, A., Asp, T., Yang, B., and Studer, B. 2016. A gene encoding a DUF247 domain protein cosegregates with the $S$ self-incompatibility locus in perennial ryegrass. Mol. Biol. Evol. 33: 870-884.

Meuwissen, T.H.E., Hayes, B.J., and Goddard, M.E. 2001. Prediction of total genetic value using genome-wide dense marker maps. Genetics 157: 1819-1829.

Miller, M.R., Dunham, J.P., Amores, A., Cresko, W.A., Johnson, E.A. (2007) Rapid and cost-effective polymorphism identification and genotyping using restriction site associated DNA (RAD) markers. Genome Res. 17: 240-248.

Newell, M.A., and Jannink, J.L. (2014) Genomic selection in plant breeding. Methods Mol. Biol. 1145: 117-130.

Pfeifer, M., Martis, M., Asp, T., Mayer, K.F.X., Lübberstedt T., Byrne, S., Frei, U., and Studer B. 2013. The perennial ryegrass GenomeZipper: targeted use of genome resources for comparative grass genomics. Plant Physiol. 161: 571582.

Sawbridge, T., Ong, E.-K., Binnion, C., Emmerling, M., Mclnnes, R., Meath, K., Nguyen, N., Nunan, K., O'Neill, M., O'Toole, F., Rhodes, C., Simmonds, J,, 
Tian, P., Wearne, K., Webster, T., Winkworth, A., and Spangenberg. G. (2003) Generation and analysis of expressed sequence tags in perennial ryegrass (Lolium perenne L.). Plant. Sci. 165: 1089-1100.

Shinozuka, H., Cogan, N.O.I., Smith, K.F., Spangenberg, G.C., and Forster, J.W. (2010) Fine-scale comparative genetic and physical mapping supports mapbased cloning strategies for the self-incompatibility loci of perennial ryegrass (Lolium perenne L.). Plant Mol. Biol. 72: 343-355.

Shinozuka, H., Cogan, N.O.I., Spangenberg, G.C., Forster, J.W. (2012) Quantitative trait locus (QTL) meta-analysis and comparative genomics for candidate gene prediction in perennial ryegrass (Lolium perenne L.). BMC Genetics 13: 101.

Soreng, R.J., Peterson, P.M., Romaschenko, K., Davidse, G., Zuloaga, F.O., Judziewicz, E.J., Filgueras, T.S., Davis, J.I., and Morrone, O. (2015) A worldwide classification of the Poaceae (Gramineae). J. Systematics Evol. 53: 117-137.

Stočes, S., Ruttink, T., Bartoš, J., Studer, B., Yates, S., Zwierzykowski, Z., Abrouk, M., Roldán-Ruiz, I., Ksiąźczyk, T., Rey, E., Doležel, J., and Kopecký, D. (2016) Orthology guided transcriptome assembly for Italian ryegrass and meadow fescue for single-nucleotide polymorphism discovery. Plant Genome 9: doi: 10.3835/plantgenome2016.02.0017.

Tu, Y., Rochfort, S., Liu, Z., Ran, Y., Griffith, M., Badenhorst, P., Louie, G.V., Bowman, M.E., Smith, K.F., Noel, J.P., Mouradov, A., and Spangenberg, G. (2010) Functional analyses of caffeic acid O-methyltransferase and cinnamoyl-CoA-reductase genes from perennial ryegrass (Lolium perenne). Plant Cell 22: 3357-3373. 
1 Xie, Y., Wu, G., Tang, J., Luo, R., Patterson, J., Liu, S., and Huang, W. (2014)

2 SOAPdenovo-Trans: de novo transcriptome assembly with short RNA-Seq 3 reads. Bioinformatics 30: 1660-1666. 


\section{Table 1.}

Transcriptome sequence statistics by library of origin.

\begin{tabular}{|c|c|c|}
\hline $\begin{array}{l}\text { Tissue name-- } \\
\text { library identifier }\end{array}$ & Description of tissue source & $\begin{array}{l}\text { Quality Sequence } \\
\text { Reads Generated }\end{array}$ \\
\hline Tip 1 & Tip of the youngest leaf from a single vegetative tiller & $82,057,679$ \\
\hline Tip 2 & $\begin{array}{l}\text { Tip of the second youngest leaf from a single vegetative } \\
\text { tiller }\end{array}$ & $83,516,188$ \\
\hline Tip 3 & $\begin{array}{l}\text { Tip of the third youngest leaf from a single vegetative } \\
\text { tiller }\end{array}$ & $67,954,787$ \\
\hline Mid 1 & $\begin{array}{l}\text { Mid-section of the youngest leaf from a single vegetative } \\
\text { tiller }\end{array}$ & $71,535,548$ \\
\hline Mid 2 & $\begin{array}{l}\text { Mid-section of the second youngest leaf from a single } \\
\text { vegetative tiller }\end{array}$ & $80,251,780$ \\
\hline Mid 3 & $\begin{array}{l}\text { Mid-section of the third youngest leaf from a single } \\
\text { vegetative tiller }\end{array}$ & $76,357,990$ \\
\hline Pseudo 1 & Complete pseudostem from a single vegetative tiller & $37,719,341$ \\
\hline Pseudo 2 & $\begin{array}{l}\text { Lower portion of the pseudostem of a single vegetative } \\
\text { tiller }\end{array}$ & $40,605,629$ \\
\hline Pseudo 3 & $\begin{array}{l}\text { Upper portion of the pseudostem of a single vegetative } \\
\text { tiller }\end{array}$ & $40,905,313$ \\
\hline Root mid & Mid-section of root mass & $39,663,070$ \\
\hline Root tip & Tip section of root mass & $40,204,367$ \\
\hline Flower & Complete flower, (un)opened & $32,437,273$ \\
\hline $\begin{array}{l}\text { Pollinated pistil } 5 \\
\text { mins }\end{array}$ & $\begin{array}{l}\text { Self-derived pollen added to pistil, then after } 5 \text { minutes } \\
\text { pistil excised and frozen }\end{array}$ & $34,693,932$ \\
\hline $\begin{array}{l}\text { Pollinated pistil } 1 \\
\text { hour minus }\end{array}$ & $\begin{array}{l}\text { Self-derived pollen added to pistil, then after c. } 1 \text { hour } \\
\text { pistil excised and frozen }\end{array}$ & $34,670,395$ \\
\hline $\begin{array}{l}\text { Pollinated Pistil } 1 \\
\text { hour plus }\end{array}$ & $\begin{array}{l}\text { Self-derived pollen already added to pistil, upon tissue } \\
\text { harvest, for an undefined time greater than } 1 \text { hour prior to } \\
\text { pistil being excised and frozen }\end{array}$ & $41,587,233$ \\
\hline $\begin{array}{l}\text { Stigma pollinated } \\
\text { Omins }\end{array}$ & Harvested following pollination at 0 minutes & $36,937,075$ \\
\hline $\begin{array}{l}\text { Stigma pollinated } \\
\text { 5mins }\end{array}$ & Harvested following pollination at 5 minutes & $43,747,723$ \\
\hline Pistil & Whole pistil & $23,111,505$ \\
\hline Anther & Whole anther & $23,590,397$ \\
\hline
\end{tabular}

